\title{
ATTITUDES OF RELATIVES TO PATIENTS IN MENTAL HOSPITALS
}

\author{
BY \\ K. RAWNSLEY, J. B. LOUDON, AND H. L. MILES \\ From the M.R.C. Social Psychiatry Research Unit, Llandough Hospital, Penarth, Glamorgan.
}

In recent years the policy of many mental hospitals in the United Kingdom has been to promote the rehabilitation and discharge of patients with chronic mental disorders. The increasing number of cases with residual symptoms living either at their homes or at institutions in closer proximity to the local population than traditional mental hospitals demands much tolerance and sympathy from relatives, friends, neighbours, and members of the general public.

The effect of the social milieu on the progress of discharged patients has been examined in studies by Brown, Carstairs, and Topping (1958) and by Freeman and Simmons (1958a,b). There is evidence from these investigations that the nature and constitution of the social group which receives the patient on discharge from hospital may exert a substantial influence upon the future course of the illness.

This paper is concerned mainly with the attitudes of relatives to a family member in a mental hospital and especially with those attitudes which may influence family behaviour if and when the time comes for the patient to leave hospital.

\section{METHOD}

A pilot inquiry was made in the Senghenydd mining valley in South Wales. This was based upon 24 patients, that is, all the people from this valley who were in a mental hospital at the time of the study.

The main study was based upon 230 patients. These propositi consisted of all persons who were in mental hospitals at the time of the survey and whose home addresses at the time of admission lay in one or other of three defined areas in South East Wales:

(1) The Rhondda Fach, a mining valley with a population of about 25,000;

(2) The Vale of Glamorgan, a rural and agricultural area with a population of about 13,000 ;

(3) The town of Barry, a small seaport and holiday resort with a population of about 40,000 .

The propositi were discovered by searching the records of local mental hospitals and by writing to private mental hospitals. The large majority of the patients were found to be in Morgannwg Hospital, Bridgend, and a few were in Whitchurch Hospital, Cardiff. These hospitals have 2,300 and 800 beds, respectively, and both are located within 20 miles of the home address of all patients who were propositi.

Each patient was seen in hospital by one of us (K.R.). An independent diagnosis was made in each case, and, wherever possible, the patient was asked for permission to get in touch with his or her relatives. Independent assessments of the patient's social potentialities were requested from three members of the hospital staff-namely, the doctor in charge of the case, the chief nursing officer, and the senior nurse in charge of the ward. A seven-point scale was used and the assessor was asked to indicate which one of the categories most appropriately described the patient's present capabilities (Table I).

TABLE I

Social Potential Scale

Assuming that the patient has a family or friends willing to receive him back home at any time, to which of the following categories would you assign the patient in his/her present state?

\section{Score}

1 Able to live in ordinary family surroundings and go out to work.

2 Able to live in ordinary family surroundings and work in sheltered employment.

3 Able to live at home but unable to work.

4 Unable to live permanently out of hospital, but able to pay visits home.

5 Unable to leave hospital at all, but capable of doing useful unsupervised work within the hospital.

6 Unable to leave hospital at all, but capable of doing ward work under supervision within the hospital.

7 Unable to leave hospital at all, and incapable of working within the hospital. 
Hospital records were consulted to discover whether the patient had been visited during the past year, and by whom. Also, a note was made of parcels delivered to the patient during the past 12 months, of letters written by relatives to the hospital authorities, and of the number of visits home overnight on leave in the past year.

The respondents for the study consisted of two relatives, where available, of each patient. Structured interviews were carried out by the investigators in the homes of respondents and these form the main source of information about the attitudes of relatives. In deciding which relatives to select for study, we were faced with a problem-clearly, some form of selection within the extended family was necessary, because it would be very difficult to estimate the attitudes of all members of each patient's kinship universe. At the same time, if the choice were restricted to just one relative for each case, this would make it impossible to form any notion of the variation in attitude between family members having a different social relationship to the patient. It might also lead to serious underestimates in such matters as the willingness of the family to make a home available for the patient. As a compromise, it was decided to select two respondents for each patient, if available. The procedure for selecting these relatives was rigid, and allowed only slight discretion to the observer.

The principal criterion for selecting the first of these two relatives (hereafter called "first respondent") was whether or not this relative had visited the patient during the past 12 months. If more than one relative had so visited the patient, the first respondent was taken as the relative highest up on a list of relationships. In the case of married patients where the first respondent was from the family of procreation, the second respondent was chosen as the highest relative on the list from the family of origin: no visiting criterion was used. For nonmarried patients the second respondent was selected from the available relatives in the next lower position on the list from the first respondent. Where the patient had received no visit in the past year, the first respondent choice was simply the available relative highest on the list. In including a visiting qualification for the first respondent, we considered that this would in general yield the relative nearest in kinship to the patient who displayed some interest in him (expressed through visiting). Also, this method of choice might avoid upsetting the family, thereby jeopardizing the chance of an interview, since it reduced the possibility that a near relative showing no interest in the patient would be interviewed, while a relative having a similar relationship and displaying great interest and concern would be ignored. (See Appendix for detailed instructions for selecting respondents.)

Interviews were restricted to relatives living in South Wales, and the great majority of them were discovered in or near the defined areas. It was decided to make the first contact with the relative by visiting rather than by writing a letter, since in this way a more detailed explanation of the purpose of the visit could be made, and any anxieties or doubts dealt with at once, with the object of forestalling refusals. This method of approach appeared quite satisfactory. In the majority of instances it was only necessary to give a brief statement of our purposes on the doorstep, mentioning our research interest, and the fact that we had seen the patient, in order to be promptly invited inside, either to conduct the interview at once, or to make an appointment to return at a more convenient time. In general, respondents seemed quite willing to answer questions about their sick relative, and appeared to speak quite freely and frankly. This is not to say that interviews were altogether devoid of strong emotion. On a number of occasions considerable feelings of guilt or anxiety about the patient, the circumstances of his admission, or the possibility of his return, were expressed. Wherever possible interviews were conducted privately, but occasionally other people were present, and the circumstances of thes home or the anxiety of other interested relatives? made it difficult to avoid this. Where specific requests for action of any kind were made by relatives, these were relayed to the psychiatric social workers in the hospital. Interviews with the first respondents were generally longer than those with the second, since a good deal of factual information about patient and family was collected from the first respondent.

\section{FINDINGS}

\section{(1) Patient Characteristics}

Distributions of the 230 patients included in the study, by sex, age at survey, civil state at survey, occupation on admission, education, duration of stay in hospital, diagnosis, and address on admission, are set out in Table II (opposite).

Because these patients comprise the total number of individuals from a defined area in hospital at a particular time, they may properly be compared in their characteristics with the total population of another mental hospital or group of hospitals which serve any given area of the country: 
TABLE II

PATIENT CHARACTERISTICS

\begin{tabular}{|c|c|c|c|c|c|c|c|c|c|c|c|c|}
\hline Sex ... & . & . & .. & . & .. & \multicolumn{2}{|c|}{ Male } & \multicolumn{3}{|c|}{ Female } & \multicolumn{2}{|c|}{ Total } \\
\hline Total No. of Patients & . & .. & . & . & .. & \multicolumn{2}{|c|}{107} & \multicolumn{3}{|c|}{123} & \multicolumn{2}{|c|}{230} \\
\hline \multicolumn{6}{|c|}{ Characteristics } & No. & Per cent. & & No. & Per cent. & No. & Per cent. \\
\hline $\begin{array}{l}\text { Age Group } \\
\text { at Survey (yrs) }\end{array}$ & $\begin{array}{l}15-\cdots \\
25-\cdots \\
35-\cdots \\
45-\cdots \\
55-\cdots \\
65-\cdots\end{array}$ & $\begin{array}{l}\cdots \\
\cdots \\
\cdots \\
\cdots \\
\cdots\end{array}$ & $\begin{array}{l}\ldots \\
\because \\
\cdots \\
\cdots \\
.\end{array}$ & $\begin{array}{l}. . \\
\cdots \\
\cdots \\
\cdots\end{array}$ & $\begin{array}{l}\cdots \\
\cdots \\
\cdots \\
\cdots \\
\cdots\end{array}$ & $\begin{array}{l}4 \\
13 \\
26 \\
23 \\
22 \\
19\end{array}$ & $\begin{array}{r}3 \cdot 7 \\
12 \cdot 1 \\
24 \cdot 3 \\
21 \cdot 5 \\
20 \cdot 6 \\
17 \cdot 8\end{array}$ & & $\begin{array}{r}2 \\
11 \\
21 \\
21 \\
23 \\
45\end{array}$ & $\begin{array}{r}1 \cdot 6 \\
8 \cdot 9 \\
17 \cdot 1 \\
17 \cdot 1 \\
18 \cdot 7 \\
36 \cdot 6\end{array}$ & $\begin{array}{r}6 \\
24 \\
47 \\
44 \\
45 \\
64\end{array}$ & $\begin{array}{r}2.6 \\
10.4 \\
20.4 \\
19 \cdot 1 \\
19.6 \\
27.8\end{array}$ \\
\hline $\begin{array}{l}\text { Civil Status } \\
\text { at Survey }\end{array}$ & $\begin{array}{l}\text { Single } \\
\text { Married } \\
\text { Widow(er) } \\
\text { Other }\end{array}$ & $\begin{array}{l}\cdots \\
\cdots \\
\cdots\end{array}$ & $\begin{array}{l}\ldots \\
\cdots \\
\cdots\end{array}$ & $\begin{array}{l}. . \\
\because \\
\cdots\end{array}$ & $\begin{array}{l}\cdots \\
\cdots \\
\cdots\end{array}$ & $\begin{array}{r}75 \\
21 \\
7 \\
4\end{array}$ & $\begin{array}{r}70 \cdot 1 \\
19 \cdot 6 \\
6.5 \\
3.7\end{array}$ & & $\begin{array}{r}53 \\
33 \\
31 \\
6\end{array}$ & $\begin{array}{r}43 \cdot 1 \\
26 \cdot 8 \\
25 \cdot 2 \\
4 \cdot 9\end{array}$ & $\begin{array}{r}128 \\
54 \\
38 \\
10\end{array}$ & $\begin{array}{r}55 \cdot 6 \\
23 \cdot 5 \\
16 \cdot 5 \\
4 \cdot 3\end{array}$ \\
\hline $\begin{array}{l}\text { Occupation } \\
\text { on Admission }\end{array}$ & \multicolumn{2}{|c|}{$\begin{array}{l}\text { Professional } \\
\text { Clerical and } \\
\text { Skilled and S } \\
\text { Miner } \\
\text { Seaman } \\
\text { Unskilled } \\
\text { Other } \\
\text { Unemployed }\end{array}$} & $\begin{array}{l}\text { Manage } \\
\text { te Colla } \\
\text { skilled } \\
\ldots \\
. \\
. \\
. \\
.\end{array}$ & $\begin{array}{l}\text { erial } \\
\text { ar } \\
\cdots \\
\cdots \\
\because \\
\cdots \\
\cdots \\
\cdots\end{array}$ & $\begin{array}{l}. . \\
\because \\
\cdots \\
\cdots \\
\because \\
\cdots\end{array}$ & $\begin{array}{r}1 \\
2 \\
18 \\
18 \\
9 \\
31 \\
16 \\
12\end{array}$ & $\begin{array}{r}0.9 \\
1.9 \\
16.8 \\
16.8 \\
8.4 \\
29.0 \\
14.9 \\
11 \cdot 2\end{array}$ & $\begin{array}{c}\text { fOwn } \\
7 \\
\frac{7}{二} \\
\frac{7}{4} \\
9 \\
5\end{array}$ & \begin{tabular}{|c|}
$\begin{array}{c}\text { Husband } \\
\text { or Father }\end{array}$ \\
2 \\
2 \\
19 \\
22 \\
4 \\
19 \\
25 \\
1 \\
\end{tabular} & $\begin{array}{r}7 \cdot 3 \\
4 \cdot 9 \\
15 \cdot 4 \\
17 \cdot 9 \\
3 \cdot 3 \\
18 \cdot 7 \\
27 \cdot 6 \\
4 \cdot 9\end{array}$ & $\begin{array}{l}10 \\
8 \\
37 \\
40 \\
13 \\
54 \\
50 \\
18\end{array}$ & $\begin{array}{r}4 \cdot 3 \\
3 \cdot 5 \\
16 \cdot 1 \\
17 \cdot 4 \\
5 \cdot 7 \\
23 \cdot 5 \\
21 \cdot 7 \\
7 \cdot 8\end{array}$ \\
\hline $\begin{array}{l}\text { Social Class* } \\
\text { (based on present or } \\
\text { last occupation) }\end{array}$ & $\begin{array}{ll}\text { I } & \cdots \\
\text { II } & \cdots \\
\text { III } & \cdots \\
\text { IV } & \cdots \\
\text { Not } & \text { Know }\end{array}$ & $\begin{array}{l}\ldots \\
\cdots \\
\cdots \\
n\end{array}$ & $\begin{array}{l}. \\
\ldots \\
\ldots \\
\ldots \\
.\end{array}$ & $\begin{array}{l}. . \\
\because \\
\cdots \\
\ldots \\
.\end{array}$ & $\begin{array}{l}\because \\
\cdots \\
\cdots \\
\cdots\end{array}$ & $\begin{array}{r}-6 \\
29 \\
37 \\
31 \\
4\end{array}$ & $\begin{array}{r}\overline{5 \cdot 6} \\
27 \cdot 1 \\
34 \cdot 6 \\
29 \cdot 0 \\
3 \cdot 7\end{array}$ & & $\begin{array}{r}1 \\
17 \\
25 \\
60 \\
13 \\
7\end{array}$ & $\begin{array}{r}0 \cdot 8 \\
13 \cdot 8 \\
20 \cdot 3 \\
48 \cdot 8 \\
10 \cdot 6 \\
5 \cdot 7\end{array}$ & $\begin{array}{l}1 \\
23 \\
54 \\
97 \\
44 \\
11\end{array}$ & $\begin{array}{r}0 \cdot 4 \\
10 \cdot 0 \\
23 \cdot 5 \\
42 \cdot 2 \\
19 \cdot 1 \\
4 \cdot 8\end{array}$ \\
\hline Education & $\begin{array}{l}\text { Elementary } \\
\text { Grammar } \\
\text { University } \\
\text { Nil and No }\end{array}$ & $\begin{array}{l}\ldots \\
\text { ot Knov }\end{array}$ & $\begin{array}{l}\ldots \\
\ddot{\text { wn }}\end{array}$ & $\begin{array}{l}. . \\
\cdots \\
\cdots\end{array}$ & $\begin{array}{l}\ldots \\
\therefore \\
\therefore\end{array}$ & $\begin{array}{r}90 \\
7 \\
2 \\
8\end{array}$ & $\begin{array}{r}84 \cdot 1 \\
6 \cdot 5 \\
1.9 \\
7 \cdot 5\end{array}$ & & $\begin{array}{r}104 \\
5 \\
5 \\
9\end{array}$ & $\begin{array}{r}84 \cdot 6 \\
4 \cdot 1 \\
4 \cdot 1 \\
7 \cdot 3\end{array}$ & $\begin{array}{r}194 \\
12 \\
7 \\
17\end{array}$ & $\begin{array}{r}84 \cdot 3 \\
5 \cdot 2 \\
3 \cdot 1 \\
7 \cdot 4\end{array}$ \\
\hline $\begin{array}{l}\text { Duration of Stay in } \\
\text { Hospital since Present } \\
\text { Admission (yrs) }\end{array}$ & $\begin{array}{r}0-\ldots \\
1-\ldots \\
2-\ldots \\
5-\ldots \\
10-\ldots \\
20-\ldots\end{array}$ & $\begin{array}{l}\cdots \\
\cdots \\
\cdots \\
\cdots \\
\cdots\end{array}$ & $\begin{array}{l}\ldots \\
\cdots \\
\cdots \\
\cdots\end{array}$ & $\begin{array}{l}. . \\
\because \\
\cdots \\
\cdots\end{array}$ & $\begin{array}{l}\cdots \\
\cdots \\
\cdots \\
\cdots \\
\cdots\end{array}$ & $\begin{array}{l}14 \\
12 \\
12 \\
20 \\
19 \\
30\end{array}$ & $\begin{array}{l}13 \cdot 1 \\
11 \cdot 2 \\
11 \cdot 2 \\
18 \cdot 7 \\
17 \cdot 7 \\
28 \cdot 0\end{array}$ & & $\begin{array}{l}38 \\
11 \\
16 \\
14 \\
20 \\
24\end{array}$ & $\begin{array}{r}30.9 \\
8.9 \\
13.0 \\
11.4 \\
16.3 \\
19.6\end{array}$ & $\begin{array}{l}52 \\
23 \\
28 \\
34 \\
39 \\
54\end{array}$ & $\begin{array}{l}22 \cdot 6 \\
10 \cdot 0 \\
12 \cdot 2 \\
14 \cdot 8 \\
17.0 \\
23 \cdot 5\end{array}$ \\
\hline Diagnosis & $\begin{array}{l}\text { Senile Psyc } \\
\text { Organic St } \\
\text { Schizophre } \\
\text { Manic Dep } \\
\text { Involutiona } \\
\text { Mental Sul } \\
\text { Epilepsy } \\
\text { Psychopath }\end{array}$ & $\begin{array}{l}\text { hosis } \\
\text { ate } \\
\text { enia and } \\
\text { pressive } \\
\text { al Depr } \\
\text { bnormal } \\
\text { hic and }\end{array}$ & $\begin{array}{l}\text {.. } \\
\text { d Paran } \\
\text { Psycho } \\
\text { ression } \\
\text { ality } \\
\ddot{\text { Neuro }}\end{array}$ & $\begin{array}{l}\ldots \\
\text { noid } S \\
\text { osis } \\
\ldots \\
\ldots \\
\text { otic St }\end{array}$ & $\begin{array}{c}\ddot{y} \\
\text { tate } \\
\ldots \\
\ldots \\
\ldots \\
\text { ates }\end{array}$ & $\begin{array}{r}4 \\
5 \\
73 \\
12 \\
5 \\
7 \\
1\end{array}$ & $\begin{array}{r}3 \cdot 7 \\
4 \cdot 7 \\
68 \cdot 2 \\
11 \cdot 2 \\
\overline{4.7} \\
6.5 \\
0.9\end{array}$ & & $\begin{array}{r}15 \\
13 \\
56 \\
11 \\
8 \\
6 \\
6 \\
8\end{array}$ & $\begin{array}{r}12.2 \\
10.6 \\
45.5 \\
8.9 \\
6.5 \\
4.9 \\
4.9 \\
6.5\end{array}$ & $\begin{array}{r}19 \\
18 \\
129 \\
23 \\
8 \\
11 \\
13 \\
9\end{array}$ & $\begin{array}{r}8.3 \\
7.8 \\
56.1 \\
10.0 \\
3.5 \\
4.8 \\
5.7 \\
3.9\end{array}$ \\
\hline Address on Admission & $\begin{array}{l}\text { Rhondda F } \\
\text { Vale of Gla } \\
\text { Barry }\end{array}$ & $\begin{array}{l}\text { Fach } \\
\text { amorgar } \\
\ldots\end{array}$ & in & $\begin{array}{l}\because \\
\therefore\end{array}$ & $\begin{array}{l}. . \\
\cdots\end{array}$ & $\begin{array}{l}47 \\
13 \\
47\end{array}$ & $\begin{array}{l}43 \cdot 9 \\
12 \cdot 1 \\
43 \cdot 9\end{array}$ & & $\begin{array}{r}47 \\
8 \\
68\end{array}$ & $\begin{array}{r}38 \cdot 2 \\
6 \cdot 5 \\
55 \cdot 3\end{array}$ & $\begin{array}{r}94 \\
21 \\
115\end{array}$ & $\begin{array}{r}40 \cdot 9 \\
9 \cdot 1 \\
50 \cdot 0\end{array}$ \\
\hline
\end{tabular}

f "Own" occupation is recorded for single and married females with a stated job other than housewife. Otherwise, husband's occupation or (for single females) father's occupation is recorded.

* Social class is determined in accordance with the Registrar General's "Classification of Occupations" (General Register Office, 1951). For females, the occupation categorized was chosen according to the rules set out in preceding footnote.

(a) Sex/Age-Specific Rate per 100,000 of the Population of Origin.-Table III (overleaf) sets out the sex/age-specific point prevalence rate for the present series alongside the comparable figures for England and Wales. The combined rate for all the age groups under consideration here is somewhat lower than the corresponding rate for England and Wales, more so for females than males. This discrepancy is due princi- pally to differences in the higher age groups.

(b) Male/Female.-The ratio of male to female patients is high by comparison with other studies of mental hospital populations (Table IV, overleaf).

(c) Age at Survey.-For both males and females the age distribution is shifted slightly to the younger 
TABLE III

SEX/AGE-SPECIFIC POINT PREVALENCE RATE PER 100,000 OF "CURRENT" POPULATION IN AREAS FROM WHICH PATIENTS WERE ADMITTED: PRESENT SERIES COMPARED WITH PATIENTS FROM ALL ENGLAND AND WALES

\begin{tabular}{|c|c|c|c|c|c|}
\hline \multirow{2}{*}{$\frac{\text { Sex }}{\text { Population }}$} & \multirow{2}{*}{$\cdots$} & \multicolumn{2}{|c|}{ Male } & \multicolumn{2}{|c|}{ Female } \\
\hline & & $\begin{array}{l}\text { Present } \\
\text { Series }\end{array}$ & $\begin{array}{c}\text { England } \\
\text { and } \\
\text { Wales }\end{array}$ & $\begin{array}{c}\text { Present } \\
\text { Series }\end{array}$ & $\begin{array}{l}\text { England } \\
\text { and } \\
\text { Wales }\end{array}$ \\
\hline$\underset{\substack{\text { Group } \\
\text { (yrs) }}}{\text { Age }}$ & $\begin{array}{l}15- \\
25- \\
35- \\
45- \\
55- \\
65-\end{array}$ & $\begin{array}{r}77 \\
234 \\
474 \\
435 \\
530 \\
530\end{array}$ & $\begin{array}{c}67 * \\
255 \\
365 \\
446 \\
618 \\
705\end{array}$ & $\begin{array}{r}37 \\
197 \\
363 \\
376 \\
483 \\
976\end{array}$ & $\begin{array}{r}53^{*} \\
180 \\
323 \\
493 \\
711 \\
1,040\end{array}$ \\
\hline \multicolumn{2}{|c|}{ All Ages Combined } & 366 & 391 & 387 & 471 \\
\hline
\end{tabular}

*For this age group the England and Wales figures are computed for ages 16-24, not 15-24.

Notes:

(1) England and Wales figures are the Registrar General's estimated sex and age distribution of resident mental hospital population at December 31, 1955.

(2) The population denominators for the present series are based on the private population census of Rhondda Fach 1958, and of Vale of Glamorgan 1961, taken by the M.R.C. Pneumoconiosis Research Unit, and in the case of Barry on the National Population Census 1951 (General Register Office, 1954).

TABLE IV

RATIO OF MALE/FEMALE PATIENTS IN PRESENT STUDY COMPARED WITH THAT IN FOUR OTHER MENTAL HOSPITAL POPULATIONS

\begin{tabular}{|c|c|}
\hline Population & Male/Female Ratio \\
\hline $\begin{array}{l}\text { Present Study } \\
\text { Thirteen Birmingham Mental Hospitals, } \\
1953 \text { (Cross, 1954) } \\
\text { England and Wales, 1957 (Mental hospitals } \\
\text { vested in the Minister of Health) (Ministry } \\
\text { of Health, 1958) } \\
\text { Four London Mentai Hospitals, 1954 (Car- } \\
\text { stairs, Tonge, O'Connor, and Barber, } \\
\text { 1955) } \\
\text { Four Birmingham Mental Hospitals, 195\% } \\
\text { (Garratt and others, 1957) }\end{array}$ & $\begin{array}{l}0.87 \\
0.76 \\
0.74 \\
0.65 \\
0.62\end{array}$ \\
\hline
\end{tabular}

end by comparison with the distribution in four Birmingham mental hospitals in 1957 (Garratt, Lowe, and McKeown, 1957), and with the Registrar General's estimate for the resident mental hospital population in England and Wales on December 31, 1956 (Registrar General, 1960) (Table V).

(d) Duration of Stay in Hospital (Present Admission). -67.5 per cent. of patients in the present inquiry have spent 2 years or more continuously in hospital. This may be compared with 76 per cent. of patients in a similar category from the resident mental hospital population in England and Wales on December 31, 1954 (Royal Commission, 1957). By comparison with the England and Wales mental hospital population in 1949, the present series shows a markedly higher proportion of females in hospital for less than one year (Table VI).
TABLE V

COMPARISON OF DISTRIBUTION OF PATIENT POPULATION IN PRESENT STUDY BY SEX AND AGE WITH THAT IN STUDIES OF FOUR BIRMINGHAM MENTAL HOSPITALS AND IN ENGLISH AND WELSH MENTAL HOSPITALS REPORTING TO THE REGISTRAR GENERAL

\begin{tabular}{|c|c|c|c|c|c|c|c|}
\hline \multicolumn{2}{|c|}{ Population. . } & \multicolumn{2}{|c|}{ Present Study } & \multicolumn{2}{|c|}{$\begin{array}{l}\text { Four Birming- } \\
\text { ham Mental } \\
\text { Hospitals, } 1957\end{array}$} & \multicolumn{2}{|c|}{$\begin{array}{c}\text { English and } \\
\text { Welsh Mental } \\
\text { Hospitals, } 1956\end{array}$} \\
\hline Sex. & . & Male & Female & Male & Female & Male & Female \\
\hline$\underset{\text { (yrs) }}{\text { Age }}$ & $\begin{array}{l}0- \\
25- \\
35- \\
45- \\
55- \\
65-\end{array}$ & $\begin{array}{r}3 \cdot 7 \\
12 \cdot 1 \\
24 \cdot 3 \\
21 \cdot 5 \\
20 \cdot 6 \\
17 \cdot 8\end{array}$ & $\begin{array}{r}1.6 \\
8.9 \\
17.1 \\
17.1 \\
18.7 \\
36.6\end{array}$ & $\begin{array}{r}2.2 \\
11 \cdot 3 \\
18 \cdot 1 \\
22.1 \\
21 \cdot 3 \\
24.9\end{array}$ & $\begin{array}{r}1.4 \\
5.6 \\
11.5 \\
16.6 \\
19.7 \\
45 \cdot 2\end{array}$ & $\begin{array}{r}2.6 \\
12.3 \\
18.0 \\
21.9 \\
21.8 \\
23.4\end{array}$ & $\begin{array}{r}1 \cdot 5 \\
6 \cdot 3 \\
11 \cdot 6 \\
18 \cdot 4 \\
23 \cdot 0 \\
39 \cdot 2\end{array}$ \\
\hline
\end{tabular}

TABLE VI

DURATION OF STAY IN HOSPITAL AND SEX OF PATIENT POPULATION IN PRESENT STUDY COMPARED WITH THAT OF THE RESIDENT MENTAL HOSPITAL POPULATION IN ENGLAND AND WALES ON DECEMBER 31, 1949 (REGISTRAR GENERAL, 1953)

\begin{tabular}{|c|c|c|c|c|c|c|}
\hline \multirow{2}{*}{$\begin{array}{l}\text { Population } \\
\overline{\text { Sex } \quad \text {. }}\end{array}$} & \multirow{2}{*}{$\cdots$} & \multirow{2}{*}{$\begin{array}{l}\cdots \\
\cdots\end{array}$} & \multicolumn{2}{|c|}{ Present Study } & \multicolumn{2}{|c|}{$\begin{array}{c}\text { English and } \\
\text { Welsh Mental } \\
\text { Hospitals, } 1949\end{array}$} \\
\hline & & & Male & Female & Male & Female \\
\hline \multicolumn{2}{|c|}{$\begin{array}{l}\text { Duration of Stay in } \\
\text { Hospital on Present } \\
\text { Admission (yrs) }\end{array}$} & $\begin{array}{c}0- \\
1- \\
2- \\
5- \\
10- \\
20-\end{array}$ & $\begin{array}{l}13 \cdot 1 \\
11 \cdot 2 \\
11 \cdot 2 \\
18 \cdot 7 \\
17 \cdot 7 \\
28 \cdot 0\end{array}$ & $\begin{array}{r}30.9 \\
8.9 \\
13.0 \\
11.4 \\
16.3 \\
19.6\end{array}$ & $\begin{array}{r}15.2 \\
7.6 \\
13.1 \\
15.0 \\
25.6 \\
23.6\end{array}$ & $\begin{array}{l}15.8 \\
7.6 \\
13.4 \\
16.0 \\
25.7 \\
21.5\end{array}$ \\
\hline
\end{tabular}

(e) Diagnosis.-By comparison with the Birmingham mental hospital population (Garratt and others, 1957), there is a lower proportion of senile psychotics of both sexes in the present series, and a higher proportion of male schizophrenics and paranoids (Table VII).

\section{TABLE VII}

COMPARISON OF DISTRIBUTION OF PATIENT POPULATION IN PRESENT STUDY BY DIAGNOSIS AND SEX WITH THAT IN A STUDY OF FOUR BIRMINGHAM MENTAL HOSPITALS

\begin{tabular}{|c|c|c|c|c|c|}
\hline Population & \multirow{2}{*}{$\begin{array}{lll}\cdots & \cdots & \cdots \\
& & \\
\end{array}$} & \multicolumn{2}{|c|}{ Present Study } & \multicolumn{2}{|c|}{$\begin{array}{c}\text { Four Birming- } \\
\text { ham Mental } \\
\text { Hospitals, } 1957\end{array}$} \\
\hline Sex & & Male & Female & Male & Female \\
\hline Diagnosis & $\begin{array}{l}\text { Senile Psychosis .. } \\
\text { Organic State } \\
\text { Schizophrenia and } \\
\text { Paranoid State } \\
\text { Manic Depressive } \\
\text { Psychosis . } \\
\text { Involutional De- } \\
\text { pression . } \\
\text { Mental Subnormal- } \\
\text { ity . } \\
\text { Epilepsy . } \\
\text { Psychopathic and } \\
\text { Neurotic States .. } \\
\text { Other Disorders .. }\end{array}$ & $\begin{array}{l}3 \cdot 7 \\
4 \cdot 7 \\
68 \cdot 2 \\
11 \cdot 2 \\
- \\
4 \cdot 7 \\
6 \cdot 5 \\
0 \cdot 9 \\
-\end{array}$ & $\begin{array}{l}12 \cdot 2 \\
10 \cdot 6 \\
45 \cdot 5 \\
8 \cdot 9 \\
6 \cdot 5 \\
4 \cdot 9 \\
4 \cdot 9 \\
6 \cdot 5 \\
-\end{array}$ & $\begin{array}{r}6 \cdot 0 \\
8 \cdot 5 \\
57 \cdot 9 \\
7 \cdot 6 \\
1 \cdot 8 \\
5 \cdot 6 \\
4 \cdot 3 \\
4 \cdot 7 \\
3 \cdot 8\end{array}$ & $\begin{array}{r}17 \cdot 9 \\
7 \cdot 1 \\
45 \cdot 6 \\
9 \cdot 1 \\
5 \cdot 8 \\
5 \cdot 7 \\
3 \cdot 5 \\
3 \cdot 6 \\
1 \cdot 5\end{array}$ \\
\hline
\end{tabular}


The distribution of the chronic patients by diagnosis approximates closely to the distribution of patients under care for 2 years or more in thirteen Birmingham mental hospitals (Cross, 1954) (Table VIII).

TABLE VIII

COMPARISON OF DISTRIBUTION OF THE CHRONIC PATIENTS (2 YRS OR MORE IN HOSPITAL) IN PRESENT STUDY BY DIAGNOSIS AND SEX WITH THAT IN A STUDY OF THIRTEEN BIRMINGHAM MENTAL HOSPITALS

\begin{tabular}{|c|c|c|c|c|c|}
\hline Population & \multirow{2}{*}{$\cdots$} & \multicolumn{2}{|c|}{ Present Study } & \multicolumn{2}{|c|}{$\begin{array}{l}\text { Thirteen Bir- } \\
\text { mingham Mental } \\
\text { Hospitals, } 1953\end{array}$} \\
\hline Sex & & Male & Female & Male & Female \\
\hline Diagnosis & $\begin{array}{l}\text { Senile Psychosis .. } \\
\text { Organic State and } \\
\text { Epilepsy .. } \\
\text { Schizophrenia and } \\
\text { Paranoid State . } \\
\text { Manic Depressive } \\
\text { Psychosis } \\
\text { Involutional De- } \\
\text { pression . } \\
\text { Mental Subnor- } \\
\text { mality . } \\
\text { Psychopathic and } \\
\text { Neurotic States .. } \\
\text { Other Disorders .. }\end{array}$ & $\begin{array}{l}- \\
12 \cdot 3 \\
75 \cdot 3 \\
6 \cdot 2 \\
- \\
6 \cdot 2 \\
-\end{array}$ & $\begin{array}{r}5 \cdot 4 \\
10 \cdot 9 \\
63 \cdot 6 \\
8 \cdot 1 \\
2 \cdot 7 \\
8 \cdot 1 \\
1 \cdot 4 \\
\end{array}$ & $\begin{array}{r}1 \cdot 4 \\
9 \cdot 9 \\
72 \cdot 4 \\
5 \cdot 2 \\
2 \cdot 9 \\
5 \cdot 9 \\
0 \cdot 7 \\
1.6\end{array}$ & $\begin{array}{r}6 \cdot 0 \\
5 \cdot 7 \\
67 \cdot 0 \\
6 \cdot 9 \\
5 \cdot 4 \\
5 \cdot 4 \\
0 \cdot 5 \\
3 \cdot 4\end{array}$ \\
\hline
\end{tabular}

\section{(2) Respondent Characteristics}

In fifteen cases ( 6.5 per cent.), it was not possible to interview a relative either because no relative was to be found in South Wales or because interview was refused. In eight instances, because of overlap between families, one respondent was interviewed for two patients (Table IX).

\section{TABLE IX}

NUMBER OF INTERVIEWS, RESPONDENTS, AND REFUSALS

\begin{tabular}{lllll|r}
\hline Total number of interviews & $\ldots$ & $\ldots$ & $\ldots$ & $\ldots$ & 384 \\
Total number of respondents & $\ldots$ & $\ldots$ & $\ldots$ & $\ldots$ & 376 \\
No relatives available & $\ldots$ & $\ldots$ & $\ldots$ & $\ldots$ & 10 \\
Refusals (patients or relatives) & $\ldots$ & $\ldots$ & $\ldots$ & $\ldots$ & 5 \\
First respondent interviews & $\ldots$ & $\ldots$ & $\ldots$ & $\ldots$ & 215 \\
Second respondent interviews & $\ldots$ & $\ldots$ & $\ldots$ & $\ldots$ & 169 \\
\hline
\end{tabular}

Table X (overleaf) sets out the distribution of the 376 respondents by sex, age, civil state, occupation, education, and relationship to patient. Siblings constitute by far the largest group, followed, in order, by parents and spouses.

\section{(3) Contact between Relatives and Patients}

Contact between a patient and his relatives can be made by a visit from the relative to the hospital or by a period of leave when the patient may visit the relative at home and perhaps stay there for a few days. Parcels and letters provide another means of communication. These actions are tangible evidence of interest on the part of relatives, though the motives which inform such interest may be varied. No record was kept of letters received by patients, though in many instances the nursing staff were able to say with confidence that a patient had received no letters for over a year. Table XI shows the extent of contact between patients and families during the preceding year. Thus 28 per cent. of the patients have not been visited for over a year and 20 per cent. have been without any kind of contact with their families.

TABLE XI

EXTENT OF CONTACT BETWEEN PATIENTS AND FAMILIES DURING THE PRECEDING YEAR

\begin{tabular}{|c|c|c|}
\hline Contact & No. & Per cent. \\
\hline 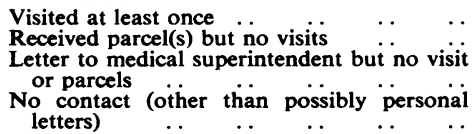 & $\begin{array}{r}165 \\
11 \\
9 \\
45\end{array}$ & $\begin{array}{r}71 \cdot 7 \\
4 \cdot 8 \\
3 \cdot 9 \\
19 \cdot 6\end{array}$ \\
\hline
\end{tabular}

The family situation for the 28 per cent. not visited in the past year is shown in Table XII, which is based on inquiries in the field and represents the nearest relative available locally. Three of the seven patients with no local family were seamen of foreign nationality admitted from the port. It is plain, therefore, that the reason why these 65 patients have not been visited for over a year does not lie in a dearth of close kin within easy travelling distance. Relatives who had not paid a visit for more than 6 months were tactfully asked why. Reasons were sometimes offered defensively and should not perhaps be taken at their face value. The commonest reason was the presence of compelling business or domestic responsibilities which made it difficult to get away. Also common was a plea of illness or old age. In 16 per cent. of cases, the patient's attitude, whether aggressive or simply unresponsive, had deterred a visit.

TABLE XII

LOCAL FAMILY SITUATION FOR PATIENTS NOT VISITED DURING PAST YEAR

\begin{tabular}{|c|c|c|c|c|}
\hline \multicolumn{4}{|c|}{$\begin{array}{cc}\text { Relative contacted and interviewed } \\
\text { Relationship: Spouse } & 7 \\
\text { Parent } & 5 \\
\text { Child } & 3 \\
\text { Sibling } & 27 \\
\text { Other } & 13\end{array}$} & 55 \\
\hline Interview refused & . & . & . & 3 \\
\hline No local family tra & $\ldots$ & $\ldots \quad \ldots$ & $\ldots$ & 7 \\
\hline
\end{tabular}

In order to examine the relationship between visiting and other variables, the frequency of visiting during the past 12 months as estimated by respondents was converted to a five-point score (Table XIII), overleaf.

Since age of patient and duration of stay in hospital show a complicated non-linear relationship to 
TABle X

RESPONDENT CHARACTERISTICS

\begin{tabular}{|c|c|c|c|c|c|c|c|c|c|c|c|c|}
\hline Sex ... & . & . & . & . & . & \multicolumn{2}{|c|}{ Male } & \multicolumn{3}{|c|}{ Female } & \multicolumn{2}{|c|}{ Total } \\
\hline Total Number & $\ldots$ & . & $\ldots$ & $\ldots$ & $\ldots$ & \multicolumn{2}{|c|}{156} & \multicolumn{3}{|c|}{220} & \multicolumn{2}{|c|}{376} \\
\hline \multicolumn{6}{|c|}{ Characteristics } & No. & Per cent. & & No. & Per cent. & No. & Per cent \\
\hline $\begin{array}{l}\text { Age Group } \\
\text { at Survey (yrs) }\end{array}$ & $\begin{array}{l}15-\ldots \\
25-\ldots \\
35-\ldots \\
45-\ldots \\
55-\ldots \\
65-\ldots\end{array}$ & $\begin{array}{l}\cdots \\
\cdots \\
\cdots \\
\cdots \\
\cdots\end{array}$ & $\begin{array}{l}\cdots \\
\cdots \\
\cdots \\
\cdots\end{array}$ & $\begin{array}{l}\cdots \\
\cdots \\
\cdots \\
\cdots\end{array}$ & $\begin{array}{l}\ldots \\
\cdots \\
\cdots \\
\cdots \\
\cdots\end{array}$ & $\begin{array}{r}2 \\
15 \\
31 \\
38 \\
30 \\
40\end{array}$ & $\begin{array}{r}1 \cdot 3 \\
9 \cdot 6 \\
19 \cdot 9 \\
24 \cdot 4 \\
19 \cdot 2 \\
25 \cdot 6\end{array}$ & & $\begin{array}{r}8 \\
16 \\
27 \\
44 \\
61 \\
64\end{array}$ & $\begin{array}{r}3 \cdot 6 \\
7 \cdot 3 \\
12 \cdot 3 \\
20 \cdot 0 \\
27 \cdot 7 \\
29 \cdot 1\end{array}$ & $\begin{array}{r}10 \\
31 \\
58 \\
82 \\
91 \\
104\end{array}$ & $\begin{array}{r}2 \cdot 7 \\
8 \cdot 2 \\
15 \cdot 4 \\
21 \cdot 8 \\
24 \cdot 2 \\
27 \cdot 7\end{array}$ \\
\hline $\begin{array}{l}\text { Civil Status } \\
\text { at Survey }\end{array}$ & $\begin{array}{l}\text { Single } \\
\text { Married } \\
\text { Widow(er) } \\
\text { Other }\end{array}$ & $\begin{array}{l}\cdots \\
\cdots \\
\cdots\end{array}$ & $\begin{array}{l}\cdots \\
\cdots \\
\cdots\end{array}$ & $\begin{array}{l}\cdots \\
\cdots \\
\cdots\end{array}$ & $\begin{array}{l}\cdots \\
\cdots \\
\cdots\end{array}$ & $\begin{array}{r}18 \\
118 \\
20 \\
-\end{array}$ & $\begin{array}{c}11 \cdot 5 \\
75 \cdot 6 \\
12 \cdot 8 \\
-\end{array}$ & & $\begin{array}{r}23 \\
142 \\
54 \\
1\end{array}$ & $\begin{array}{r}10 \cdot 5 \\
64 \cdot 5 \\
24 \cdot 5 \\
0 \cdot 5\end{array}$ & $\begin{array}{r}41 \\
260 \\
74 \\
1\end{array}$ & $\begin{array}{r}10 \cdot 9 \\
69 \cdot 1 \\
19 \cdot 7 \\
0 \cdot 3\end{array}$ \\
\hline $\begin{array}{l}\text { Occupation } \\
\text { at Survey }\end{array}$ & \multicolumn{2}{|c|}{$\begin{array}{l}\text { Professional } \\
\text { Clerical and } \\
\text { Skilled and S } \\
\text { Miner } \\
\text { Seaman } \\
\text { Unskilled } \\
\text { Other } \\
\text { Unemployed } \\
\text { Supervisory }\end{array}$} & $\begin{array}{l}\text { Manage } \\
\text { e Collar } \\
\text { killed } \\
\ldots \\
\ldots \\
\ldots \\
\ldots \\
\ldots\end{array}$ & $\begin{array}{l}\text { erial } \\
\text { ir } \\
\ldots \\
\ldots \\
\ldots \\
\cdots \\
\cdots \\
\cdots \\
\cdots\end{array}$ & $\begin{array}{l}\cdots \\
\cdots \\
\cdots \\
\cdots \\
\cdots \\
\cdots \\
\cdots\end{array}$ & $\begin{array}{r}7 \\
4 \\
36 \\
39 \\
2 \\
32 \\
29 \\
1 \\
6\end{array}$ & $\begin{array}{r}4 \cdot 5 \\
2 \cdot 6 \\
23 \cdot 1 \\
25 \cdot 0 \\
1 \cdot 3 \\
20 \cdot 5 \\
18 \cdot 6 \\
0 \cdot 6 \\
3 \cdot 8\end{array}$ & $\begin{array}{c}\text { fOwn } \\
6 \\
7 \\
2 \\
- \\
-1 \\
19 \\
1 \\
2\end{array}$ & \begin{tabular}{|c|}
$\begin{array}{c}\text { Husband } \\
\text { or Father }\end{array}$ \\
6 \\
10 \\
48 \\
44 \\
6 \\
29 \\
32 \\
1 \\
6
\end{tabular} & $\begin{array}{r}5 \cdot 4 \\
7 \cdot 7 \\
22 \cdot 7 \\
20 \cdot 0 \\
2 \cdot 7 \\
13 \cdot 6 \\
23 \cdot 2 \\
0 \cdot 9 \\
3 \cdot 6\end{array}$ & $\begin{array}{r}19 \\
21 \\
86 \\
83 \\
8 \\
62 \\
80 \\
3 \\
14\end{array}$ & $\begin{array}{r}5 \cdot 1 \\
5 \cdot 6 \\
22 \cdot 9 \\
22 \cdot 1 \\
2 \cdot 1 \\
16 \cdot 5 \\
21 \cdot 3 \\
0 \cdot 8 \\
3 \cdot 7\end{array}$ \\
\hline $\begin{array}{l}\text { Social Class* } \\
\text { based on Present or } \\
\text { Last Occupation }\end{array}$ & $\begin{array}{l}\text { I } \quad \ldots \\
\text { II } \quad \cdots \\
\text { III } \quad \cdots \\
\text { IV } \quad \cdots \\
\text { V } \\
\text { Unclassifia }\end{array}$ & $\begin{array}{c}\ldots \\
\cdots \\
\cdots \\
\ddot{a b l e}\end{array}$ & $\begin{array}{l}\cdots \\
\cdots \\
\cdots \\
\cdots\end{array}$ & $\begin{array}{l}\ldots \\
\ldots \\
\ldots \\
\cdots \\
\cdots\end{array}$ & $\begin{array}{l}\cdots \\
\cdots \\
\cdots \\
\cdots \\
\cdots\end{array}$ & $\begin{array}{r}\overline{22} \\
35 \\
76 \\
21 \\
2\end{array}$ & $\begin{array}{l}1 \overline{4} \cdot 1 \\
22 \cdot 4 \\
48 \cdot 7 \\
13 \cdot 5 \\
1 \cdot 3\end{array}$ & & $\begin{array}{r}-\overline{37} \\
64 \\
92 \\
21 \\
6\end{array}$ & $\begin{array}{r}\overline{16 \cdot 8} \\
29 \cdot 1 \\
41 \cdot 9 \\
9 \cdot 5 \\
2 \cdot 7\end{array}$ & $\begin{array}{r}-59 \\
99 \\
168 \\
42 \\
8\end{array}$ & $\begin{array}{r}1 \overline{15 \cdot 7} \\
26 \cdot 4 \\
44 \cdot 6 \\
11 \cdot 2 \\
2 \cdot 1\end{array}$ \\
\hline Education & \multicolumn{3}{|c|}{$\begin{array}{ll}\text { Elementary } & \ldots \\
\text { Grammar } \ldots & \ldots \\
\text { University } \ldots & \ldots \\
\text { Nil and Not } & \text { Known }\end{array}$} & $\begin{array}{l}\cdots \\
\cdots \\
\cdots\end{array}$ & $\begin{array}{l}\cdots \\
\cdots \\
\cdots\end{array}$ & $\begin{array}{r}137 \\
16 \\
3 \\
-\end{array}$ & $\begin{array}{r}87 \cdot 8 \\
10 \cdot 3 \\
1 \cdot 9 \\
-\end{array}$ & & $\begin{array}{r}194 \\
20 \\
5 \\
1\end{array}$ & $\begin{array}{r}88 \cdot 2 \\
9 \cdot 1 \\
2 \cdot 3 \\
0 \cdot 5\end{array}$ & $\begin{array}{r}331 \\
36 \\
8 \\
1\end{array}$ & $\begin{array}{r}88 \cdot 0 \\
9 \cdot 6 \\
2 \cdot 1 \\
0 \cdot 3\end{array}$ \\
\hline $\begin{array}{l}\text { Relationship } \\
\text { to Patient }\end{array}$ & $\begin{array}{l}\text { Spouse } \\
\text { Parent } \\
\text { Child } \\
\text { Sibling } \\
\text { Aunt or U } \\
\text { Nephew or } \\
\text { Cousin } \\
\text { Other }\end{array}$ & $\begin{array}{l}\ldots \\
\ldots \\
\ldots \\
\text { Uncle } \\
\text { r Niece } \\
\ldots \\
\ldots\end{array}$ & $\begin{array}{l}\cdots \\
\cdots \\
\cdots \\
\cdots \\
\cdots \\
\cdots\end{array}$ & $\begin{array}{l}\ldots \\
\cdots \\
\cdots \\
\cdots \\
\cdots \\
\cdots\end{array}$ & $\begin{array}{l}\ldots \\
\cdots \\
\cdots \\
\cdots \\
\cdots \\
\cdots\end{array}$ & $\begin{array}{r}27 \\
16 \\
20 \\
75 \\
6 \\
8 \\
3 \\
5\end{array}$ & $\begin{array}{r}16 \cdot 9 \\
10 \cdot 0 \\
12 \cdot 5 \\
46 \cdot 9 \\
3 \cdot 7 \\
5 \cdot 0 \\
1 \cdot 9 \\
3 \cdot 1\end{array}$ & & $\begin{array}{r}16 \\
43 \\
22 \\
98 \\
9 \\
12 \\
10 \\
14\end{array}$ & $\begin{array}{r}7 \cdot 1 \\
19 \cdot 2 \\
9 \cdot 8 \\
43 \cdot 7 \\
4 \cdot 0 \\
5 \cdot 4 \\
4 \cdot 5 \\
6 \cdot 2\end{array}$ & $\begin{array}{r}43 \\
59 \\
42 \\
173 \\
15 \\
20 \\
13 \\
19\end{array}$ & $\begin{array}{r}11 \cdot 2 \\
15 \cdot 4 \\
10 \cdot 9 \\
45 \cdot 1 \\
3 \cdot 9 \\
5 \cdot 2 \\
3 \cdot 4 \\
4 \cdot 9\end{array}$ \\
\hline
\end{tabular}

TABLE XIII

CONVERSION OF VISITING FREQUENCY TO A SCORE

\begin{tabular}{c|c}
\hline $\begin{array}{c}\text { No. of Visits by a Given Respondent } \\
\text { During Past Year }\end{array}$ & $\begin{array}{c}\text { Respondent's } \\
\text { Visiting Score }\end{array}$ \\
\hline 0 & 0 \\
$1-3$ & 1 \\
$4-11$ & 2 \\
$12-25$ & 3 \\
$26-$ & 4 \\
\hline
\end{tabular}

each other, the relationship between these two variables and respondents' visiting score is perhaps best displayed graphically, dividing the patients into three age groups and four length of stay categories on the same graph (Fig. 1, opposite). Although the mean visiting score is inversely related to the duration of stay in hospital, there appears to be no substantial consistent difference in the visiting activity of res- pondents towards older patients compared with younger after standardizing for duration of stay.

Mean visiting scores have been computed for the respondents for single and married patients (widowed and other marital conditions are not included). The scores have been controlled for duration of stay in hospital, since visiting frequency has been found to be related to this variable and since the long-stay groups have a higher proportion of single patients than the short-stay (Table XIV, opposite).

The average visiting score is higher for married than for single patients in all sex/duration-of-stay categories except for females in hospital for 10 years or more. Taking the scores for patients in hospital for less than 10 years, analysis of variance indicates a difference between the single and married groups significant at the 2 per cent. level. The variance due 


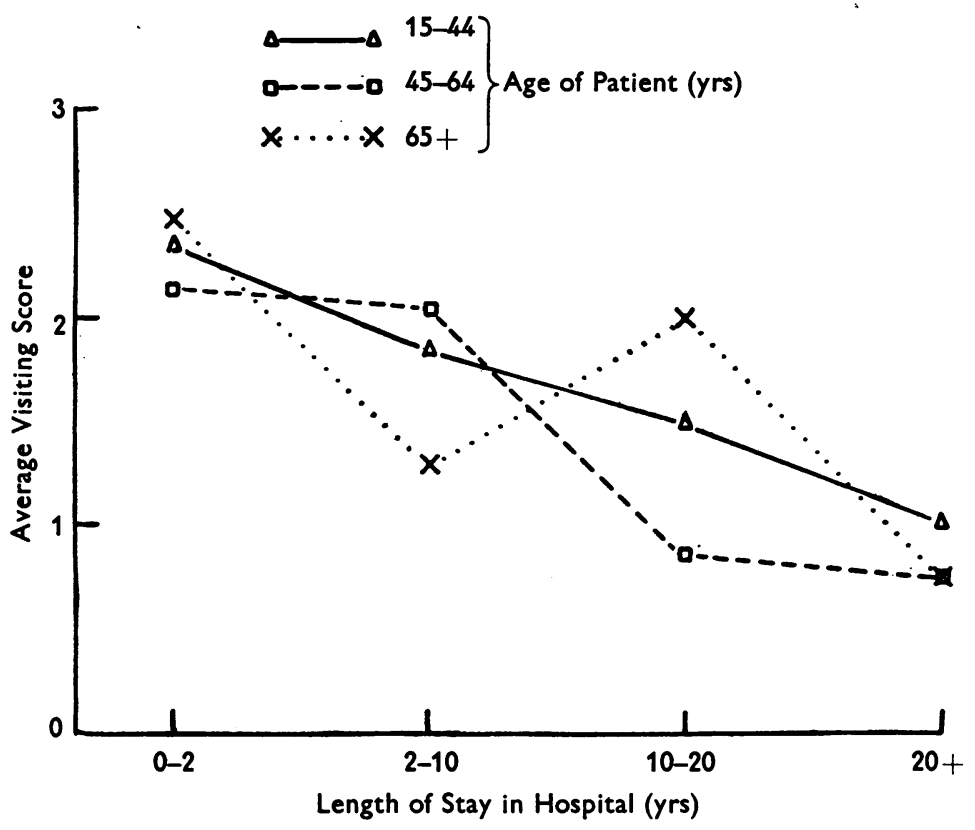

FIG. 1.-Visiting scores for respondents, by age of patient and duration of stay in hospital.

TABLE XIV

AVERAGE VISITING SCORES FOR RESPONDENTS OF SINGLE AND MARRIED PATIENTS BY SEX AND DURATION OF STAY IN HOSPITAL

\begin{tabular}{|c|c|c|c|c|c|c|c|}
\hline \multicolumn{2}{|c|}{$\begin{array}{l}\text { Duration of Stay } \\
\text { in Hospital (yrs) }\end{array}$} & \multicolumn{2}{|c|}{$0-2$} & \multicolumn{2}{|c|}{$2-10$} & \multicolumn{2}{|c|}{$10+$} \\
\hline \multicolumn{2}{|c|}{ Civil Status } & Single & $\overline{\text { Married }}$ & $\overline{\text { Single }}$ & $\overline{\text { Married }}$ & $\overline{\text { Single }}$ & $\overline{\text { Married }}$ \\
\hline \multirow{2}{*}{$\begin{array}{c}\begin{array}{c}\text { Sex } \\
\text { of } \\
\text { Patient }\end{array} \\
\end{array}$} & Male & $2 \cdot 0$ & $2 \cdot 6$ & $1 \cdot 7$ & $2 \cdot 1$ & 0.8 & $2 \cdot 1$ \\
\hline & Female & $2 \cdot 0$ & $2 \cdot 5$ & $1 \cdot 8$ & $2 \cdot 2$ & $1 \cdot 3$ & 0.6 \\
\hline
\end{tabular}

to sex is negligible, as is also the variance due to interaction between sex and marital status.

Since the derived visiting score is not an equal interval scale, the use of parametric statistics may be called in question. The non-parametric rank " $t$ " test (Bross, 1954) applied to the data, however, gives a very similar result in that the difference between single and married patients is significant at the 2 per cent. level (rank $t=2 \cdot 32$; d.f. 189).

A similar tabulation has been made for schizophrenics only, but restricting the length of stay to less than 2 years (Table XV). Again, the average visiting score is higher for married than for single patients, but the difference is not statistically significant.

TABLE XV

AVERAGE VISITING SCORES FOR RESPONDENTS OF SINGLE AND MARRIED SCHIZOPHRENICS (DURATION OF STAY IN HOSPITAL 2 YEARS OR LESS)

\begin{tabular}{|c|c|c|c|}
\hline Civil Status & .. & Single & Married \\
\hline \multirow{2}{*}{ Sex of Patient } & Male & 1.9 & $3 \cdot 0$ \\
\hline & Female & $1 \cdot 9$ & $2 \cdot 7$ \\
\hline
\end{tabular}

The method of selecting respondents provides an interesting opportunity for comparing the average visiting scores of different categories of relative. Because both a visiting criterion (where possible) and kinship were used for selection, first respondents constitute in the main a group of the nearest relatives to show some interest. If a sibling is selected, this usually means that spouse, child, and parents are 
absent for one or another reason and therefore that the sibling's sense of obligation to the patient is likely to be operating at maximum level. Fig. 2 presents average visiting scores controlled for duration of stay in hospital for spouses, children, parents, and siblings who are first respondents. Scores for members of the family of procreation (spouse and child) are closely similar and show a progressive decline in the longer-stay categories. The scores for members of the family of origin (parents and siblings) do not begin to fall until over 10 years' stay: parents show consistently higher scores than siblings.

Visiting records were checked again 2 months after the conclusion of field work; 58 patients in the original group had been in hospital for over a year and had been without a visitor for over a year. In eleven instances (19 per cent.) the patient had now been visited by one or other of the relatives interviewed.

\section{(4) Social Potential Scale}

The technique for assessing each patient's social potential has already been mentioned (Table I). Analysis of variance for the total group of patients shows no significant difference between the three categories of observer: doctors, chief nurses (or matrons), and charge nurses (or sisters). An aggregate rating was therefore constructed for each patient by adding together the three scores which had been obtained independently. The aggregate score range is 3-21. Table XVI sets out the distribution of all patients according to this aggregate score. The mean score for each category of observer is also stated.
TABLE XVI

DISTRIBUTION OF PATIENTS BY RATING ON SOCIAL POTENTIAL SCALE

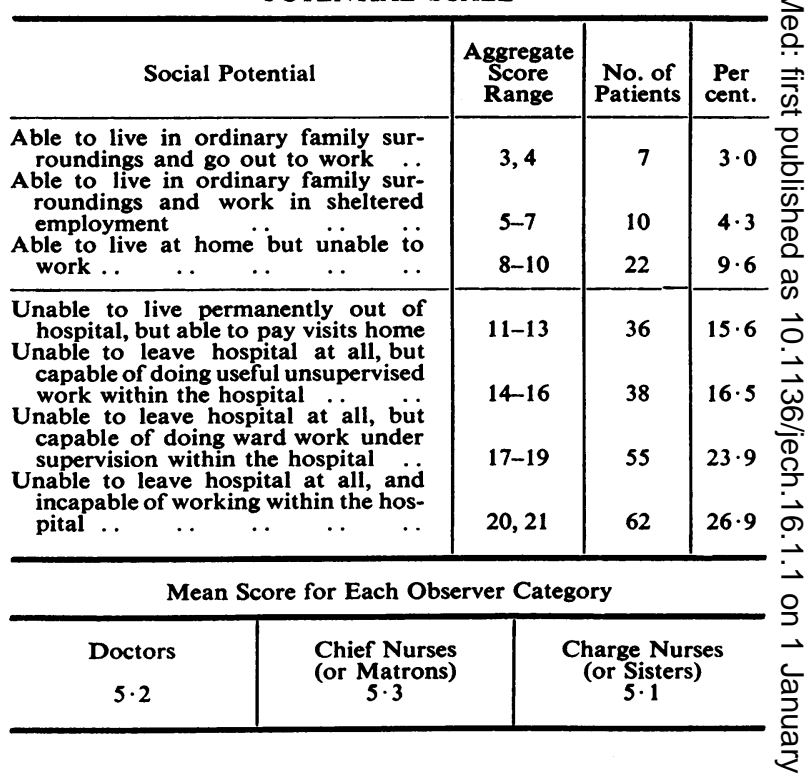

Every patient therefore has an aggregate hospital $\vec{\bullet}$ rating. Aggregate scores within the range 3-10 of the social potential scale are regarded as meaning that the patient is well enough to live at home; score of $11-13$, that the patient may go home on leave; 14-21, that neither discharge nor even leave is justified. An attempt was made during the interview to obtain a comparable estimate from each respondent.

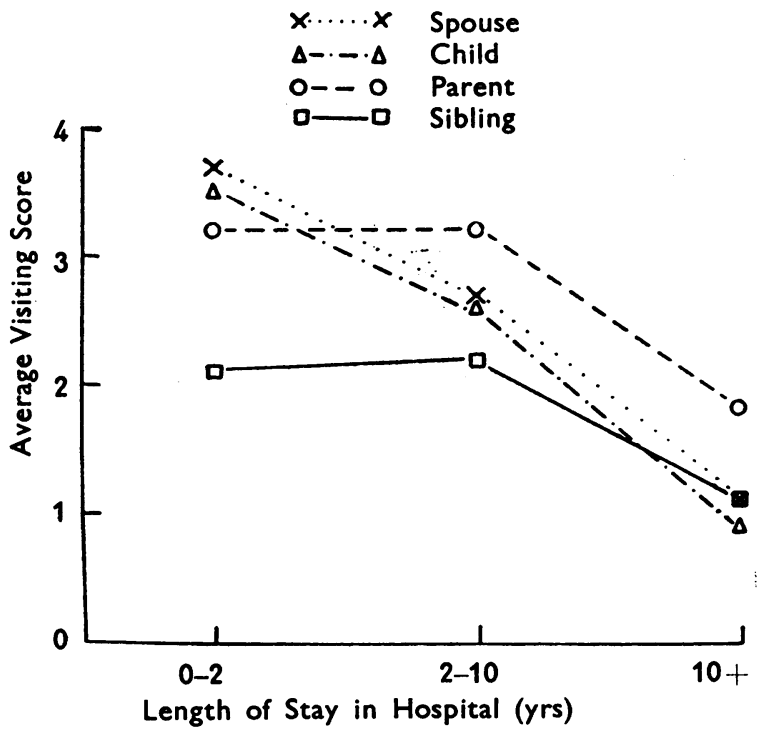

Fig. 2.-Average visiting scores, by duration of stay in hospital for spouses, children, parents, and siblings who are first respondents. 
Those respondents who had seen the patient during the past year or since admission were asked whether, in their opinion, the patient was well enough $(a)$ to spend a weekend away from the hospital; $(b)$ to be discharged. These views of respondents about patients' present capabilities are compared with the views of hospital staff in Table XVII.

There are two entries for each patient, because in those cases where two respondents were available, the respondents' estimates of social capacity might, and often did, differ. The lowest row in the Table includes entries for respondents who could not form an opinion ("don't knows"); for respondents who were not asked for an opinion because they had not seen the patient recently ("not applicables"), and for instances in which a respondent or respondents were not available.

Using the log likelihood ratio test, there is a significant positive association between the attitudes of relatives and hospital staff in respect of patients' social capabilities. (Males $G=40.8131$; d.f. 4; $p<0.001$. Females $G=17.1631$; d.f. $4 ; p<0.01$ ). Despite this, there are many instances, especially among the female patients, where widely discordant opinions are to be found.

\section{(5) Prospect of Employment}

Respondents were asked whether patients had a specific job to return to on discharge and, if not, what were their prospects of finding work in the locality. At the time of the survey, 64 patients were 65 years old or more; for the rest, respondents' views have been pooled to give the most optimistic prognosis for securing a job on discharge. Nine males had jobs to return to and twenty were thought to have a good chance of obtaining work-i.e. 33 per cent. of the eligible men. Of 78 eligible women, six had jobs waiting and fifteen were considered likely to find work-27 per cent. in all.
(6) Willingness of Family Members to Accommodate Patients in the Event of Discharge

Several questions were asked to explore the availability of a home for the patient in the event of recovery sufficient to warrant discharge. Among these were questions to assess the personal willingness of the respondent to accommodate the patient and also the difficulties involved in acceptance, in terms of space, money, health of household members, and emotional resistance. Respondents' attitudes were classified as follows:

(a) Willing to accept the patient without difficulty.

(b) Willing to accept the patient, but with some difficulty.

(c) Doubtfully willing to accept the patient.

(d) Unwilling to accept the patient.

The first tabulation in this section (Table XVIII) sets out the situation for all patients, excluding five patients in whose case interviews had been refused. Each patient is classified according to the best personal offer of accommodation by one or other respondent. The ten patients with no family that could be traced are placed in the lowest category. Taking the first two categories together, 60 per cent. of patients could rely upon their families to accommodate them, judging by the statements of family members.

\section{TABLE XVIII}

BEST PERSONAL OFFER OF ACCOMMODATION BY RELATIVES FOR EACH PATIENT (EXCLUDING FIVE INTERVIEW REFUSALS)

\begin{tabular}{|c|c|c|}
\hline Offer of Accommodation & No. & Per cent. \\
\hline 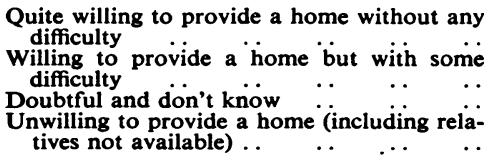 & $\begin{array}{r}109 \\
26 \\
11 \\
79\end{array}$ & $\begin{array}{r}48 \cdot 4 \\
11 \cdot 6 \\
4 \cdot 9 \\
35 \cdot 1\end{array}$ \\
\hline
\end{tabular}

TABLE XVII

COMPARISON OF VIEWS OF HOSPITAL STAFF ABOUT PATIENTS' SOCIAL CAPACITY WITH RESPONDENTS' OPINIONS

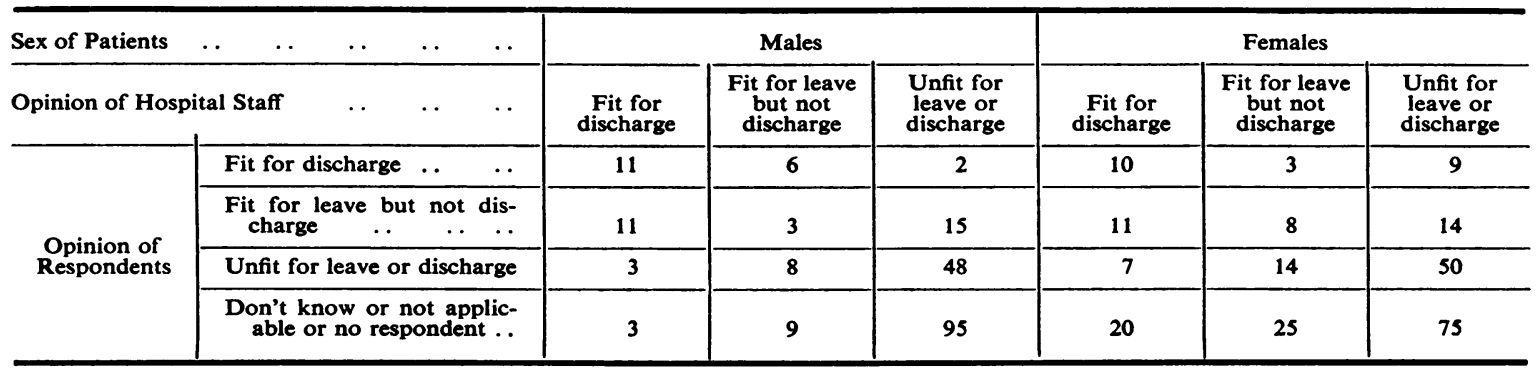


It seemed likely that the willingness of families to receive their relatives on discharge would depend, in part, upon the age of the patient and the duration of stay in hospital. The relationship between these three variables is displayed in Fig. 3. The ordinate shows the percentage of respondents for each age/length-ofstay subgroup who would be willing to receive the patient on discharge either without difficulty or with some specified difficulty. With the exception of patients in hospital for less than 2 years, the proportion of respondents willing to receive patients is inversely related to the age of the patient in a striking manner. There is also a reduction in the proportion of willing relatives with increasing duration of stay, though this is relatively slight for the two youngest age groups, but very marked for patients aged 65 or more. Indeed, no patient aged $65+$ who has been in hospital for 10 years or more can count on the family providing a home.

Table XIX sets out the percentage of respondents willing to accommodate single and married schizophrenic patients who had been in hospital for less than 2 years. The absolute numbers involved are small here and, although the married patients are more favoured in their prospects of accommodation than the single patients, the difference is not statistically significant.

TABLE XIX

PERCENTAGE RESPONDENTS PERSONALLY WILLING TO PROVIDE A HOME ON DISCHARGE FOR SINGLE

AND MARRIED SCHIZOPHRENICS (DURATION OF STAY IN HOSPITAL 2 YEARS OR LESS)

\begin{tabular}{|c|c|c|c|c|}
\hline Civil Status & .. & .. & Single & Married \\
\hline \multirow{2}{*}{ Sex of Patient } & Male & $\ldots$ & 63 & 83 \\
\hline & Female & & 33 & 50 \\
\hline
\end{tabular}

The relationship between stated availability of a home in the event of discharge, and the degree of interest shown by relatives in terms of visiting is examined in Table XX (opposite). All the patients, except for five for whom interviews were refused, are sub-divided, first according to the best offer of accommodation by one or other respondent, and secondly according to whether the patient has received at least

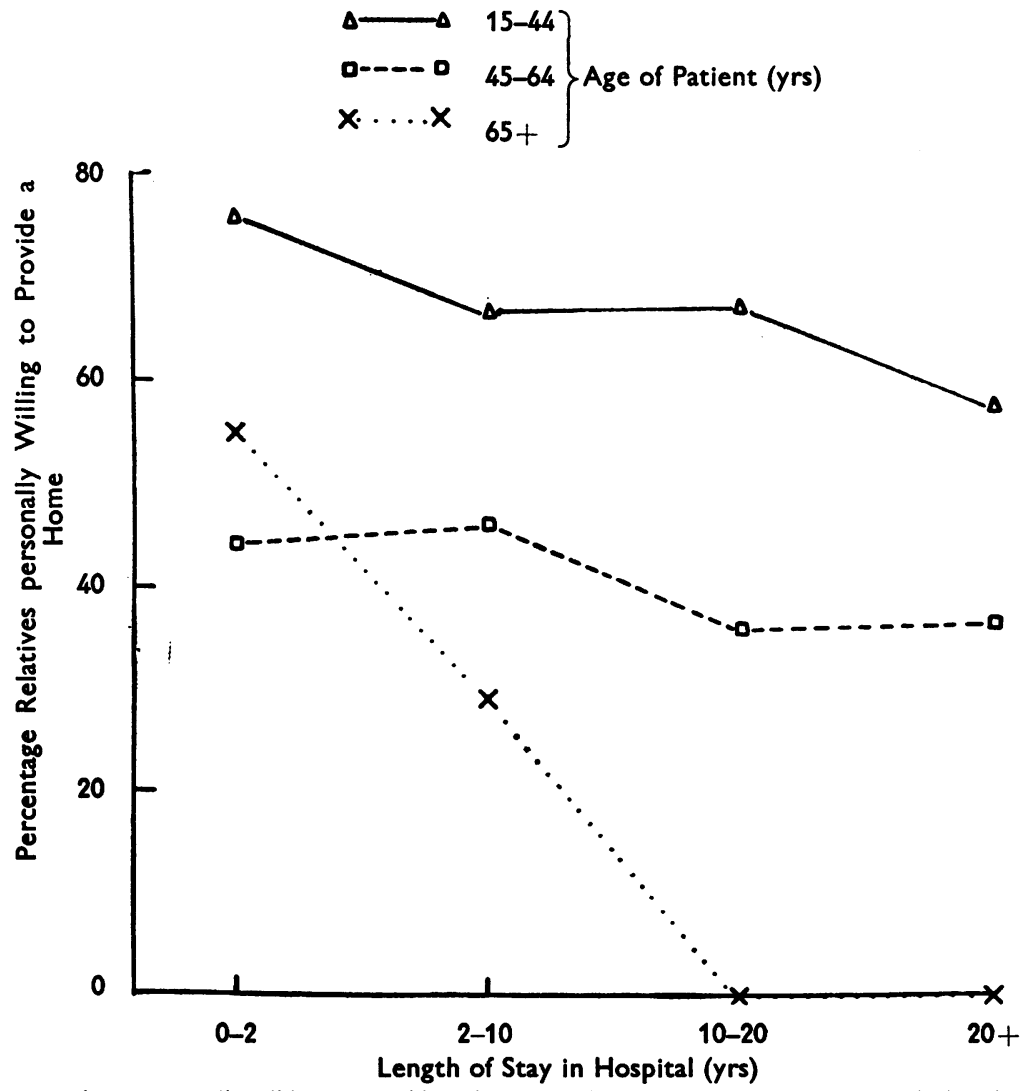

Fio. 3.-Percentage respondents personally willing to provide a home on discharge, by age of patient and duration of stay in hospital. 
TABLE XX

BEST PERSONAL OFFER OF ACCOMMODATION BY RELATIVES FOR EACH PATIENT ACCORDING TO WHETHER PATIENT HAS RECEIVED AT LEAST ONE VISIT IN PAST YEAR (EXCLUDING 5 INTERVIEW REFUSALS)

\begin{tabular}{|c|c|c|c|c|}
\hline \multirow{2}{*}{ Offer of Accommodation } & \multicolumn{2}{|c|}{ Visited } & \multicolumn{2}{|c|}{ Not Visited } \\
\hline & No. & $\begin{array}{l}\text { Per } \\
\text { cent. }\end{array}$ & No. & $\begin{array}{l}\text { Per } \\
\text { cent. }\end{array}$ \\
\hline $\begin{array}{l}\text { Willing to provide a home .. } \\
\text { Can provide a home with some diffi- } \\
\text { culty } \\
\text { Doubtful and don't know } \ldots \\
\text { Unwilling to provide a home }\end{array}$ & $\begin{array}{r}98 \\
23 \\
8 \\
38\end{array}$ & $\begin{array}{r}58 \cdot 7 \\
13 \cdot 8 \\
4 \cdot 8 \\
22 \cdot 7\end{array}$ & $\begin{array}{r}11 \\
3 \\
3 \\
41\end{array}$ & $\begin{array}{r}18 \cdot 9 \\
5 \cdot 2 \\
5 \cdot 2 \\
70 \cdot 7\end{array}$ \\
\hline
\end{tabular}

one visit in the past year. The ten patients with no local families have had no visits in the past year and are regarded as having no prospect of a home on discharge. There is a strong association between the occurrence of a visit during the past year and the prospect of acceptance home by the family (combining 1st and 2 nd and combining 3 rd and 4th categories of willingness, $\chi^{2}=39.9 ; 1$ d.f.; $p<0.001$ ).

It should, however, be noted that of patients out of contact with their families for one year or more, 24 per cent. have at least one relative who declared himself willing to receive them on discharge.

(7) Social Potential and the Prospect of a Home ON Discharge

From Table XVI it may be noted there are 39 patients capable of living at home in their present condition. Some of these were short-stay patients who were recovering rapidly and would probably be discharged within a week or two. Of these 39 patients there are fourteen who have an aggregate social potential score of 10 or less, who have been in hospital during the present admission for one year or more, and who have at least one relative personally willing to accommodate them on discharge. To restate this finding, fourteen patients $(6 \cdot 1$ per cent. of the total) have been in hospital for more than a year, are regarded by the hospital staff as capable of living at home in their present state, and have relatives who have declared a willingness to provide accommodation for them.

\section{(8) Area Differences}

Of the 230 patients investigated, 94 had been admitted from the Rhondda, 21 from the Vale of Glamorgan, and 115 from Barry. The distribution of these patients by age shows a statistically significant variation between the three areas (Table XXI). The Rhondda has a high proportion of younger patients by comparison with the Vale, where the middle age groups preponderate. Barry yielded the
TABLE XXI

DISTRIBUTION OF ALL PATIENTS BY AGE AT SURVEY AND ADDRESS ON ADMISSION

\begin{tabular}{|c|c|c|c|c|c|c|c|}
\hline \multirow{2}{*}{\multicolumn{2}{|c|}{$\begin{array}{l}\text { Address on } \\
\text { Admission }\end{array}$}} & \multicolumn{2}{|c|}{$\begin{array}{l}\text { Rhondda } \\
\text { Fach }\end{array}$} & \multicolumn{2}{|c|}{$\begin{array}{c}\text { Vale of } \\
\text { Glamorgan }\end{array}$} & \multicolumn{2}{|c|}{ Barry } \\
\hline & & No. & $\begin{array}{c}\text { Per } \\
\text { cent. }\end{array}$ & No. & $\begin{array}{c}\text { Per } \\
\text { cent. }\end{array}$ & No. & $\begin{array}{l}\text { Per } \\
\text { cent. }\end{array}$ \\
\hline $\begin{array}{l}\text { Age Group at } \\
\text { Survey (yrs) }\end{array}$ & $\begin{array}{l}15- \\
25- \\
35- \\
45- \\
55- \\
65-\end{array}$ & $\begin{array}{r}4 \\
16 \\
19 \\
17 \\
16 \\
22\end{array}$ & $\begin{array}{r}4 \cdot 3 \\
17 \cdot 0 \\
20 \cdot 2 \\
18 \cdot 1 \\
17 \cdot 0 \\
23 \cdot 4\end{array}$ & $\begin{array}{l}-\overline{2} \\
7 \\
6 \\
3 \\
3\end{array}$ & $\begin{array}{l}\overline{9 \cdot 5} \\
33 \cdot 3 \\
28 \cdot 6 \\
14 \cdot 3 \\
14 \cdot 3\end{array}$ & $\begin{array}{r}2 \\
6 \\
21 \\
21 \\
26 \\
39\end{array}$ & $\begin{array}{r}1 \cdot 7 \\
5 \cdot 2 \\
18 \cdot 3 \\
18 \cdot 3 \\
22 \cdot 6 \\
33 \cdot 9\end{array}$ \\
\hline
\end{tabular}

highest proportion of older patients. There was insignificant variation in other patient characteristics between the three areas-namely, male:female ratio, duration of stay in hospital, and diagnosis. Taking respondent characteristics, the variation between the areas in the distribution by sex and by age was not significant, but that in the distribution of relationship between respondents and patients was significant (for spouse, parent, child, sibling, and other: $\chi^{2}=$ $19 \cdot 36 ; 8$ d.f.; $p<0 \cdot 01$ ). The proportion of siblings was fairly constant throughout, but the proportion of other near relatives (spouse, parent, and child) was maximal in the Vale, intermediate in Barry, and minimal in the Rhondda.

Comparison of the frequency with which patients from the three areas were visited by respondents showed no significant variation. There was, however, a substantial difference in the stated willingness of relatives to provide accommodation on discharge. Barry patients possessed the highest proportion of frankly unwilling respondents ( 52 per cent.) by comparison with the Rhondda (38 per cent.) and the Vale (32 per cent.) $\left(\chi^{2}=17.4\right.$; d.f. $\left.6 ; p<0.01\right)$. Now visiting frequency has been shown to be independent of patient's age when length of stay in hospital is standardized, whereas readiness to provide a home is very sensitive to age. Since Barry has a relatively high proportion of older patients, it may be supposed that this is the reason for the comparative lack of hospitality which Barry patients can anticipate. This factor, however, does not entirely account for the situation, since a similar pattern emerges when all the patients are stratified by age into three groups. For each age group thus constituted, Barry patients are the least favourably placed for promise of a home on leaving hospital.

\section{A Note on Observer Differences}

The interviews for the present study were carried out using a schedule of questions administered in fixed order and having a standard form of words. The interviewer 
filled in the responses as they occurred during the session and in many of the questions this meant encircling one or other of a small number of alternative answers. The extent to which the interviewer was required to "process" the response in his own mind before recording the answer varied from question to question. For some questions it was necessary occasionally to make a rather complicated judgment. The three interviewers were jointly responsible for the design of the study, including the construction of the interview schedule. In an attempt to assess variations due to interviewer differences eighty patients from the Barry group were allocated at random to the three interviewers and a separate analysis of this material has been made. The log likelihood ratio test has been used to examine the significance of differences in the distribution of patient and respondent characteristics and of responses to interview questions in the three subsamples. There was no significant difference between the three samples in the distribution of patients by sex, age, diagnosis, and duration of stay in hospital. There was likewise no significant difference in distribution of respondents by sex, age, and relationship to patient. Distribution of responses to questions at interview about frequency of visiting and also about degree of willingness to provide accommodation on discharge showed no significant difference between the three interviewers. It may be worth mentioning here that another section of the interview schedule devoted to exploring attitudes to mental hospitals showed significant differences between the three observers on a number of the questions. This material is not reported in the present paper.

\section{Discussion}

One of the early surprises in carrying out the field work was the discovery of relatives, usually close relatives, living locally in the large majority of those cases unvisited for a year or more. The fact that a few of these relatives visited the hospital almost immediately after the interview without any direct prompting suggests that visiting habits might be stimulated fairly easily if thought desirable. Often, relatives had moved from the address quoted on the hospital records and a little detective work was necessary to locate them. Inquiries were always made in person rather than by letter, and it seems likely that letters written to many of the addresses known to the hospital would have been returned by the post office.

A quarter of the unvisited patients was found to have relatives willing to offer accommodation on discharge. This evidence runs counter to what is, perhaps, the more usual view expressed, for example, by Gore and Jones (1961), that patients visited annually or less frequently "clearly do not have families or friends who would be prepared to support them in the event of discharge". It is obvious that a verbal offer made in an interview situation may not be honoured in the event. This finding implies, how- ever, that a mental hospital pursuing a vigorous rehabilitation policy for long-stay patients would do well to make an active local search for relatives in the case of patients apparently long-forgotten by their families before deciding to place them in lodgings or in a hostel.

The small group of patients $(6 \cdot 1$ per cent.) fit to live at home (according to the hospital staff), with a home waiting for them (according to the family), and with continuous hospital residence of a year or more, would appear to be promising candidates for rehabilitation. There is evidence, however, that contact with close relatives at home may have a deleterious effect upon certain schizophrenic patients (Brown, Carstairs, and Topping, 1958), and there is little doubt that family life may be disrupted, in some instances, by the returning patient. More work is urgently needed to examine the social adjustment of discharged patients and of the families to which they return. Leaving aside the difficult question whether any given patient will suffer less by exposure to the potentially damaging influence of long residence in hospital than by exposure to potentially damaging social relationships within the family, the implication of the finding mentioned at the beginning of this paragraph may be stated: unless there is a clear contraindication, action should be considered in line with the concordant attitudes of staff and relatives who both say, in effect, this patient can and may live at home. 8,800 patients living in English and Welsh mental hospitals in 1959 would fall into this category if the proportion found in the present survey could be generalized.

The difficulty of realization probably lies mainly in the shortage of staff, especially social workers who, given the eligible patients, and having identified receptive families, could arrange and supervise the discharge process and smooth out the social complications. The bulk of medical and social work endeavour is concentrated upon the short-stay group of patients and upon extra-mural services, and relatively little staff-time may be available for work with the chronic patients. In the present survey a note was made of any recorded contact between the hospital social workers and the patients or their families. Such contact had occurred in 20 per cent. of patients in hospital for less than 2 years, but in only 7 per cent. of other patients.

The finding that 16.9 per cent. of the present series (Table XVI) might leave hospital if a home were available may be compared with the figure of 12.4 per cent. which was the proportion of patients requiring no hospital facilities in the opinion of 
psychiatrists participating in the survey of Birmingham mental hospital residents (Garratt, Lowe, and McKeown, 1957; 1958). There is a difference, however, between the two groups, in that slightly more than half of the Birmingham patients requiring no hospital facilities were not thought suitable for discharge home. Despite this limitation, "they needed no personal supervision, but they did need to live in an organized community which could provide assistance with such matters as training and employment".

Analysis of visiting frequency and of willingness to accommodate patients by age and length of stay in hospital indicates that, although interest expressed through visiting is sustained in the elderly group of patients, this is not matched by willingness to house them. Judging by the responses of relatives, it is clear that a policy which seeks to discharge long-stay elderly patients of either sex must look for accommodation outside the family. The provision of special hostels for the elderly long-stay patient with mild symptoms is an obvious solution. Social work with families would be best reserved for the younger groups, whatever their length of stay in hospital.

The relationship between civil state, visiting frequency, and availability of accommodation on discharge in the case of schizophrenics less than 2 years in hospital is of interest, in view of previous work on the differential probability of discharge for single and married patients. Norris (1956) showed that, amongst schizophrenic admissions in 1947-49 to some London hospitals, single patients had the greatest chance of retention for 2 years, and that the married had least, with the widowed and divorced occupying an intermediate position. Brooke (1959) showed that 19 per cent. of single schizophrenic first admissions in England and Wales in 1954-56 were still alive and in hospital 2 years later, while 12 per cent. of the patients who had been married at some time were likewise retained. Wing, Denham, and Monro (1959) found that single schizophrenic patients in two cohorts of admissions to Long Grove Hospital had a worse prognosis for discharge within 2 years than married patients.

In the present series, although the numbers in this category are small, married schizophrenics of less than 2 years' stay command a higher level of active interest (as judged by visiting frequency) and better prospects of accommodation on discharge. The influence of these social factors on the chance of leaving hospital is not likely to be offset by clinical differences, since the average social potential ratings (taken as an index of present clinical severity) are not dissimilar for the two groups (males: single 13.9, married 14.3; females: single $11 \cdot 2$, married $10 \cdot 3$ ).
One important factor not systematically examined in this study is the attitude of the patients themselves to their future, and, in particular, to the prospect of leaving hospital. Although many patients would undoubtedly prefer an early discharge, others are too apprehensive or too settled to want it. Folkard (1960) found that the expectations of a group of selected chronic patients regarding prospects of discharge, and level of performance after discharge, were more optimistic than those expressed by their relatives. Wing (1960) has shown that the desire of some chronic male schizophrenics to leave hospital can be substantially sharpened by exposing them to an Industrial Rehabilitation Course at a Ministry of Labour Unit.

Comparison of the attitudes of respondents to patients from the three areas has shown that, despite equivalence of "active interest" revealed through visiting, Barry patients have a substantially higher proportion of relatives unwilling to house them on discharge, and that Vale of Glamorgan patients are the most favourably placed in this respect. Since "unwillingness" appears to follow degree of urbanization in the three areas, it is tempting to assume a functional connexion between the two variables. It may be predicted that "unwillingness" levels may be even higher in the conurbations.

The prevalent mental hospital population deriving from a particular geographical area is influenced in its characteristics by several factors, including the recent social and demographic history of the area, and the policy pursued over many years by the mental hospitals concerned. This consideration, together with the obvious factor of cultural variation, gives pause to the facile extrapolation of these findings to other localities or to the country as a whole. The inter-area differences discovered in the present study, even when the principal mental hospital was a constant factor, serve to reinforce this caution. Nevertheless, although there would undoubtedly be many differences in detail in the findings of a similar survey carried out elsewhere, it is possible that the general pattern of relationships found here would be sustained.

\section{SUMMARY}

This is a study of the prevalent mental hospital in-patient population from three defined areas and of the attitudes of local kin towards this group. Patients were assessed by the hospital staff in terms of their social potentiality. Attitudes of relatives were studied principally by home interviews conducted 
with a sample of relatives from each family and by the examination of records of contacts between patients and their families in the hospital.

Local kin were extant in 97 per cent. of all the cases and in 89 per cent. of those patients who had been without a visitor for a year or more.

60 per cent. of all patients and 24 per cent. of those without a visitor for a year or more could rely upon their families providing accommodation on discharge.

Active interest by relatives is negatively correlated with duration of stay but is unrelated to age of patient when standardized for duration of stay. Degree of willingness to accommodate the patient on discharge, however, is negatively related both to duration of stay and to age of patient.

$6 \cdot 1$ per cent. of the series have been in hospital continuously for more than a year, are regarded by the hospital staff as capable of living at home in their present state, and have relatives who have declared a willingness to provide accommodation for them.

Married patients in general command a higher level of active interest from their relatives than single patients. Married schizophrenics, in hospital for less than 2 years, attract greater interest and have better prospects of a home on discharge than single schizophrenic patients.

There was a significant measure of agreement between hospital staff and relatives about the social potential of patients.

The degree of "active interest" taken by relatives in patients from each of the three areas is approximately equal; but, in the event of discharge, relatives seem to be more willing to accommodate patients admitted from the rural area than those admitted from urban areas.

The administrative implications of the findings are discussed.

We are indebted to the Medical Superintendent of Morgannwg Hospital, Bridgend, Dr. M. W. Annear, and to his predecessor, the late Dr. C. J. Morgan; to the Medical Superintendent of Whitchurch Hospital, Cardiff, Dr. J. P. Spillane, and his predecessor, Dr. T. J. Hennelly, for permitting access to patients in these hospitals and for their full co-operation. We wish to record our thanks to the medical and nursing staffs of these hospitals for assistance in making the social potential ratings. We are very grateful to Professor A. L. Cochrane, Hon. Director of the M.R.C. Epidemiological Research Unit, and to Dr. J. C. Gilson, Director of the M.R.C. Pneumoconiosis Research Unit, for providing facilities on a generous scale to enable us to work in South Wales. We thank Mr. P. D. Oldham, Senior Statistician of the Pneumoconiosis Research Unit for his advice and help.

\section{REFERENCES}

Brooke, E. M. (1959). Proc. roy. Soc. Med., 52, 280.

Bross, I. D. J. (1954). Fed. Proc., 13, 815.

Brown, G. W., Carstairs, G. M., and Topping, G. (1958). Lancet, 2, 685.

Carstairs, G. M., Tonge, W. L., O'Connor, N., and Barber, L. E. D. (1955). Brit. J. prev. soc. Med., 9, 187.

Cross, K. W. (1954). Ibid., 8, 29.

Folkard, S. (1960). Ibid., 14, 23.

Freeman, H. E., and Simmons, O. G. (1958a). Amer. sociol. Rev., 23, 147. (1958b). Soc. Forces, 37, 153.

Garratt, F. N., Lowe, C. R., and McKeown, T. (1957). Brit. J. prev. soc. Med.. 11, 165. (1958). Ibid., 12, 23.

General Register Office (1951). "Classification of Occupations, 1950”. H.M.S.O., London.

(1954). Census 1951 England and Wales: County Report, Glamorganshire. H.M.S.O., London.

Gore, C. P., and Jones, K. (1961). Lancet, 2, 544.

Ministry of Health (1958). "Report for 1957, Part I". H.M.S.O., London.

Norris, V. (1956). J. ment. Sci., 102, 467.

Registrar General (1953). "Statistical Review of England and Wales for 1949. Supplement on General Morbidity, Cancer and Mental Health." H.M.S.O., London.

1954-56.). "Supplement on Mental Health". H.M.S.O. London.

Royal Commission (1957). "Royal Commission on the Law relating to Mental Illness and Mental Deficiency. 1954-1957. Report." H.M.S.O., London.

Wing, J. K. (1960). Brit. J. prev. soc. Med., 14, 173.

—, Denham, J., and Monro, A. B. (1959). Ibid., 13, 145.

\section{APPENDIX}

\section{SELECTION OF RESPONDENTS}

A. Two relatives should be interviewed, where posible, for each patient.

B. If patient has had visitors in last 12 months, then visitor highest up on the list of relationships will be the first respondent.

C. List of relationships:

(1) Spouse

(2) Children

(3) Mother

(4) Father

(5) Siblings

(6) Aunts

(7) Uncles

(8) Cousins, nephews and nieces. 
D. In-laws succeed cousins in hierarchical order (mother-in-law, father-in-law, etc.).

E. For married patients, one respondent should be taken from the family of procreation, the other from the family of orientation (opposite sex if possible).

F. Divorced or separated spouses are not to be interviewed.

G. Lower age limit 18 years.

$\mathrm{H}$. If patient is single and has two parents, siblings, and/or other relatives, then interview:

(1) Mother

(2) Sibling or relative of opposite sex if possible.
I. If patient is single and has no parents, but has siblings and other relatives, then interview:

(1) Sibling (sister before brother)

(2) Other relative of opposite sex if possible.

\section{Notes}

(1) If visitor highest on the list refuses, interview next on the list irrespective of visiting habits.

(2) In the case of $(a)$ refusal, $(b)$ relative living at a distance, and (c) psychotic or physically ill relative (where communication is difficult), interview the next relative on the list and make a note about the circumstances. 